\title{
Divergent Perspectives and Social Style in Conflict Talk
}

\section{Werner Kallmeyer \& Inken Keim}

\begin{abstract}
In this paper, we analyze a dramatically aggravated conflict interaction taking place in the course of an association's meeting in an urban community center. The interaction can be seen as the culmination point of a social conflict developing and increasing over a period of years. In this conflict, one of the crucial points of the sociocultural development in the city under study is to be seen in an exemplary way. Our analysis started with the question, why this conflict is unsolvable although the interest divergences of the opposing parties are not irreconcilable. Our analysis shows that the protagonists practice different communicative social styles. These stylistic differences however, are not the cause for misunderstandings, but the protagonists use stylistic differences and different cultural orientations as a resource for political action. Thereby a process of increasing hardening of perspective divergence emerges together with an interaction modality of drama and of the fundamental grounding of divergent views. Theoretically we are concerned with the explication of a sociolinguistic theory which includes as constitutive components the concepts of communicative social style, of perspectivation and of interaction modality. We want to show, that the analyzed type of sociocultural conflict can be explained by virtue of considering the interplay of features on these three levels.
\end{abstract}

\section{Introduction}

The research context of the paper is an ethnographically based sociolinguistic study of different communicative social styles within the urban population of Mannheim, an industrial German town of about 300.000 inhabitants.' A specific communicative social style is defined by various features of verbal and nonverbal behavior such as phonological variation, patterns of syntactical structures, special meanings of lexical items, formulaic speech, pragmatic rules of politeness and special ways of conflict management. ${ }^{2}$ Used in a systematic way in the communication, these features are perceived as traits of one complex figure which has social meaning and whose consistency is produced by some basic principles of formation. Our concept of communicative social style is influenced by the an- 
thropological and ethnographic concept of cultural style. ${ }^{3}$ In this tradition, cultural style is the product of the adjustment of human communities to their ecological, social and economical conditions. The principles for forming a style correspond to distinctive features of a cultural paradigm in contrast to another. In this perspective, a social style has a fundamentally strategic grounding, and is defined as the specific cultural solution for existential needs. The specific character of a cultural style becomes obvious by a comparison across different social worlds. Practices of stylistic variation, as described in linguistic and sociolinguistic stylistics, ${ }^{4}$ are constitutive to our concept of style, too; but we understand them as practices of an inner-social-world variation.

In it's totality, the present case analysis takes into account participant observation, ethnographic interviews and transcribed tape recordings of verbal interactions documenting a fundamental conflict within a community center in an area of the inner city of Mannheim. This is the area of a traditional working class culture. ${ }^{5}$ The protagonists are, on the one side, a politically known figure of the local population who has been elected as president of the association running the community center, and, on the other side, a group of academically trained social workers employed by the center. The documented materials of this conflict were compared with other documents of political actions in this area, where the local population is confronted with people of the community administration and the urbanistic planning staff.

In this paper, we will concentrate on some aspects of the interaction in the most dramatic meeting at the community center. This interaction was taperecorded, and our paper is based on the conversation analysis of this document of about three hours. For economic reasons we prefer to present the case in a condensed and more narrative way, because the analyzed communicative phenomena stretch over long sequences of the interaction. To give an impression of the protagonists' communicative style, we only fill in small examples of the discoursive phenomena we are interested in.

From the point of view of a sociolinguist, interested in the study of verbal and social dynamics, the case under study highlightens a point of friction which can be seen in other parts of our study too. The historical development of the ordinary people's district, the Filsbach, led to a manifest separation from the Mannheim center and to a distantiation from the urban institutions. People from outside the local area who wanted to support the local social life and the local culture were not accepted by the Filsbach population. There are many opportunities for the competition of divergent paradigms of culture and social style. Often this cultural conflict is less obvious, sometimes the knowledge of the cultural difference is used in a subversive way. The case we present here, a conflict about the "right" 
kind of work and work organization in the community center, is the most dramatic case of a cultural conflict which we documented in this local area.

In the course of the dramatic meeting at the community center, participants attach much significance to differences in the communicative style of the protagonists. Systematic analysis reveals that the stylistic features, specific to the local world such as the indirectness in conflict management and special processes of symbolizing social identity and moral qualities, contrast widely with the forms of argumentation and social evaluation used by the academically trained social workers.

The role of these divergent practical realizations of communicative social style in the aggravation of the conflict could be interpreted as the product of a cultural misunderstanding caused by different "cultural codes" (see Gumperz 1978). But despite of the participants' defining the conflict as a fundamental problem of style we shall argue, that it is not the existence of sociostylistic differences as such which creates misunderstandings and aggressiveness. It is much more the protagonists' using these differences as resources in order to polarize the own and the others' positions. At least in part these different discourse practices are functionalized as political devices. In certain aspects this comes close to the establishing of ethnic boarders by miscommunication (see Barth 1969; McDermott \& Gospodinoff 1979$)^{6}$, but we think that in our case, there is still another element at the root of the conflict dynamic: participants establish a specific interaction modality of "fundamentally speaking". ' In this respect, special forms of perspective work, that is of manifesting one's own perspective and of coping with the opponents' are as crucial as the explicit references to social style and to concepts of communicative norms. Finally participants are caught in a sort of "social drama" (Turner 1975) with a negative outcome.

\section{The Case under Study: The Natural History of a Conflict}

The community center "Begegnungsstätte Westliche Unterstadt" (situated in the "lower west side" of the inner city of Mannheim) is run by an association on public funds; the association's program consists of various recreational activities for the local population, for Germans and foreigner groups. ${ }^{8}$

During the urban renewal in the 70ties, the association was founded by idealists from outside the local area, who wanted to make the district attractive as an living area. At the beginning, the association's recreational program was run by members of the association who worked unpaid. But in reaction to the increasing demand for social work, the association decided to hire socially trained educationalists, and to recruit new members. This resulted in a complete change of the association's status. Diverse groups arose with different ideas about the associa- 
tion's goals. These groups blocked up each other's work and perceived each other as "cliques". The organization of the association's work became more and more complicated and conflict ridden. Because of the internal conflict situation, the newly hired educationalists' work was not to be controlled over a longer period of time, so that they could take liberties which they would not have taken under a strict reglementation.

Many members were discontent with the state of affairs, especially with the management and the employees' working results. Six weeks before the outbreak of the conflict, some members wanted to reorganize the association: the manageress, a highly motivated person, but who felt overworked; some of the older members who founded the association; some who suffered from the cliquism as Klaus, a student, who, for one year, had done social work in the association (as "civil service", instead of the military service), and who knows the structure of the association as well as the kind of socio-pedagogical work which is needed; and finally Walter Zehner, one of the local population who entered the association a year ago.

Particularly Zehner's commitment to the association's reorganization was seen as a lucky chance: he was one of the local population, had already been successful in local politics, and he had time to do unpaid social work. A new board was elected with Walter Zehner and Klaus as board members, and Zehner as president.

The newly elected board started immediately a program in order to put the association's work back on its feet again. Zehner checked the management, he examined the qualifications of the employees and their working results, and he came to the conclusion that a severe mismanagement had occurred. Zehner's actions provoked a massive resistance on the employees' side who saw their jobs jeopardized. The former president, Vera, a young student, regarded Zehner's inspections as a fundamental criticism of her work. Against the new board a coalition was formed, consisting mainly of the employees and the members of the former board. They regarded Zehner as socially incompetent, and they rejected his reforming plans as inadequate means. In the forth week after the election, the new board called an extraordinary general assembly, a type of meeting which implies strong restrictions on the topics to be dealt with and on the members' participation, and which provides for decisions on the staff.

At this meeting, all conflict parties are present. From the very beginning, two parties confront each other: on the one side the new board and the "reformers", on the opposing side the employees, the former board and lots of members, newly recruited by the employees. The main figures of the board are the new president Zehner and Klaus. Their goals on this extraordinary meeting are: criticizing the 
employees' work, proving that the manageress made severe mistakes, and bringing about decisions against the staff; establishing a new work order, which strictly takes into account the juridical prescriptions as well as the association's statutes and rules; and establishing the president as boss of the employees. The opponents' goal is to hinder the president's plans and to justify the work done, and the former managing practices.

For a long time, both parties do not reveal their motives, and the battle takes place in the course of debates about technical procedures (permissibility of the application of new members, discussions about the invitation being sent within the specified time, special items of the agenda, a.s.o.). With the very first exchange of statements the political and strategic qualities of the whole argument become obvious. This brings about an atmosphere of mistrust and suspicion, manifesting itself in the opponents' reproaching each other of not being frank and open, and attributing negative motives to their respective moves.

The new board loses the argument; its opponents prove that Zehner made formal faults when he prepared the extraordinary general assembly, and they achieve in redefining the assembly's formal status as an ordinary meeting. This means that the board can not use some of the most powerful formal devices for controlling the situation; and the board loses the formal basis for carrying through its reforming plans. The resistance of the audience is particularly put up to Zehner; Klaus causes much less protest. The opponents manifestively attempt to split the board and to isolate Zehner.

After the redefinition of the meeting, the main items of the agenda are the reports of the board's members and of the employees. These reports develop into extended fundamental statements displaying the speakers' work concept, and expressing a deeply grounded criticism on the work concept and the communicative behavior of the opposing side. The conflict reaches its climax when Zehner accuses the manageress of "criminal practices". In protest against Zehner, the audience confirms the appointment of the manageress; with this, Zehner is definitely defeated. In the course of the meeting Zehner's supporters had dissociated themselves from him. On the day after, the members of the board resign.

A short time later, a new board is elected. Again, an outsider is called for president. He is not a Filsbacher like Zehner, but a person on intimate terms with the association's members' social world. He finally succeeds in reforming the association's work organization.

One of the members who first supported Zehner's reforming plans but dissociated herself from him in the course of the meeting, retrospectively gives as reason for Zehner's failure: he wanted to do right, but he acted in a "proletarian manner". 


\section{Some Sociostylistic Characteristics of the Protagonists}

Because it is, especially, Zehner's actions which rise the audience's protest, we want to present some of the main features of his communicative behavior. These features will be contrasted with Klaus' way of acting which evoked far less critical reactions. The main features of Klaus's communicative social style resemble very much those of his opponents.

\subsection{Linguistic variation and specific rhetoric features of the committee language of a Mannheim dialect speaker}

Zehner's language is characterized by a wide range of linguistic variation between standard German and the Mannheim dialect. In the meeting, the stylistic variation in his speech follows the typical patterns of variation practice of a Mannheim dialect speaker who acts skillfully in public and institutionalized settings. ${ }^{9}$ The default level of his speech style comes close to the German standard, that is, the proportion of Standard elements is high and dominates long phases of talk. In relation to this default level, stylistic variation serves a variety of functions. ${ }^{10}$ It can serve as a speech structuring device, or it can be used symbolically to refer to specific social characteristics of activities: A special kind of marked standard is used when formal and institutional activities are performed (i.e. submitting an application), or when norms, statutes or moral principles are invoked. A special kind of exaggerated standard is used for purposes of irony or sarcasm or to refer to someone's strange or deviant social behavior. A linguistic variety close to the dialect is used when role-specific routine actions are performed, acquaintances are addressed, or other speakers' statements or reproaches are rejected in a non-ironic fashion. In addition, the dialectal realization of comments exhibits the speakers own perspective.

Zehner's variation practice which is typical of the social milieu of ordinary local people in Mannheim, does not cause a strangeness to the association's members coming from different social worlds. Their language too has a dialectal character like that of most people in Mannheim, and they are very much familiar with this type of speech.

Zehner's speech appears particularly weighty and affected whenever his arguments are made out to be grounded in the law. In those cases he uses the typical non-academic Mannheim dialect speaker's "legalese" as a marked form of committee language. This register is regularly used, for example, in community meetings. His use of this committee-language is characterized by various lexicosyntactical features such as complex lexical constructions like sich um die aufnahme bewerben" ("to apply for admission"), refined lexical expressions such as es bedarf einer satzungsänderung ("a change in by-laws is required"), with a 
very infrequent genitive construction, and numerous passive constructions. But the most distinctive features of this variety are paired idiomatic formulae and, more generally, coupling constructions (some examples: ich habe die ehre und das vergnügen als vorstand hier gewählt worden zu sein, "it is an honor and a pleasure to me to be elected to the board of this association"; weder nach satzung noch nach geschäftsordnung, "neither according to the statutes nor according to the by-laws"; weder vereinsrechtlich noch juristisch, "neither according to the statutes of the association nor according to the law"; es ist für den verein nicht und hier nicht gültig, "this is legally binding neither here and now nor for the association generally"; die das gar nicht wissen können und gar nicht wissen muissen, "people who neither can nor have to know it".)

Zehner is the only one who uses these formulation patterns, at least in this marked form. The dialect speaking academic people at the meeting - most of Zehner's opponents as well as the other members of the board - use other forms to mark an emphatic speech modality. But we think that this rhetoric specificity is not very important on it's own to define Zehner as culturally distant in his opponents' perspective; at least no immediate reactions to it can be observed. More interesting, however, are those features of Zehner's communicative conduct, which are explicitly characterized and negatively evaluated by his opponents, and whose potential of aggravating a conflict is either pointed out by them or transpires from their reactions: Zehner's authoritarian style, and his implicit and indirect conflict management.

\subsection{The authoritarian manner of the Filsbacher}

Zehner's opponents perceive his communicative style as authoritarian and call it diktatorisch (dictatorial). In their contributions, they especially emphasize that he is unwilling to discuss issues and to cooperate with them, and they denounce his authoritarian way of giving instructions and establishing the new work regulations which he has created. Their reproaches are grounded in their own, contrasting communicative paradigm, a paradigm which is based upon notions of negotiation and of dealing with conflict through argumentation.

The authoritarian manner is an essential educational device in the social world of the "Filsbach" to which Zehner belongs. ${ }^{12}$ It includes harsh reprimands and clear given instructions for action which are not to be questioned. If they are questioned nevertheless, this is understood as a fundamental criticism of one's actions and of social norms that are generally respected. A person, who defies an instruction, can expect punishment. The orientation toward this educational model is quite common in the Filsbach world and appears even in asymmetrical relationships among adults, for example, in specific marital constellations (such as the "Hausdrachen-Hampelmann"-constellation) $)^{13}$ as well as in other forms of 
social organizations, e.g. in associations. In this social world, when acting in an authoritarian manner, the president of an association does no more than to establish and demonstrate his authority in the expected way. In fulfilling his role as a member of the board, Zehner follows the rules of the communicative paradigm that is common in his own social world. ${ }^{14}$

There are mainly three characteristics that constitute Zehner's authoritarian manner in the meeting: harsh rebukes, the apodictive stating of norms, and the dispreference for argumentative discussion and parliamentarian procedures.

\subsubsection{Harsh rebukes}

Right at the beginning of his first turn, Zehner reprimands one of the audience's members who talks softly with his neighbor: du kriggsch des wort noch rechtzeitig ("you be getting your turn in due time"), asking him indirectly to be quiet. In this fashion, he reveals his annoyance with the member's momentary inattendance, and demonstrates that he is not willing to allow anyone to engage in side-activities. His demand for total attention at the very beginning of his speech reveals his view about the authority of a president.

A moment later, when Vera, the former president, is about to relate how she previously decided in a comparable matter, Zehner internupts her harshly by saying: <nei" $n$ * mir beschränken uns auf geschä "ftsordnung und satzung ("no, we only go by the statutes and the rules"). Because he presents his exclusive reliance upon norms and statutes as an argument, he implies that she did not rely upon them, and that her arguments are therefore irrelevant. By cutting short the other's utterance, Zehner manifests his concept of a president's extended power of topic control in the debate.

\subsubsection{The setting of norms and standards}

As the last example illustrated, Zehner decides without discussion on the acceptability of arguments. In the same way, he defines what is the correct interpretation of the statutes. He determines was unzweifelhaft ist ("what is undoubted") and worüber es keine diskussion geben kann ("what is not to be discussed"). He extends his exclusive right to interpret what is proper procedure so that it even covers the former president's decisions. He determines that the way in which admissions to the association had formerly been handled was against the statutes: es is an der satzung un der geschäftsordnung vorbei " gemacht worden * und is rechtlich * $i$ "rrelevant * und so ** für den * verein * ni"cht und hie " $r$ nicht gültig ("it is against the statutes and the rules and therefore legally irrelevant, it is not legally binding, not here and now and not for the association in general"). Without asking for further information about the former president's past decision, he challenges the legal competence of his predecessors; he condemns a decision 
the entire association had previously agreed with; and he demands authority exclusively for himself.

The impression of decisiveness in Zehner's conduct results from a variety of verbal devices: He supports his political position with extensive quotes from the statutes and by-laws; he makes extensive use of linguistic markers of decisiveness to organize the closing of an argumentative exposition, for example, so weit so gut ("so far so good"), das war das ("that was that"); and, frequently, he asserts the indisputability of facts: des is juristisch so klar ("in legal terms, this is absolutely clear"), or des is so unzweifelhaft darïber kann=s auch im rahmen des vereins keine diskussion geben ("this is so unquestionable and there can't be any discussion about it, not even in this association").

Zehner's authoritarian manner has disastrous effects on the employees. As they see it, Zehner dictates the new work order and the new scheduling of working hours that he has prepared for them, and he forbids any discussion about it. He declares that his view of the association's new order is the "normal" one, and he presupposes that there is a general consensus which is shared by the employees as well. He regards their opposition against his new order as a personal attack.

In contrast, Klaus shows a more egalitarian manner. He does not present his own position as generally valid and binding, but he qualifies it as his opinion, or as a suggestion, i.e.: so " is dieser ablauf und danach * schlag ich vor * müssen wir uns richten ("this is the course of the action and, this is my suggestion, we should follow it"). Even a legally well-founded position is not presented as obligatory but as a recommendation, and he gives reasons for it. And he often claims common ground with his opponents and in doing so, shortens the distance between the opposing parties. For example, he takes up with the statement and the "we"-category his opponent, the former president, had offered in her previous speech and establishes, at least for a short time, a common view on a subject matter. And he includes his opponents when reflecting on actual problems of the association, and he aims at a cooperative solution. This is revealed in formulations like was machen wir mit...("what are we going to do with..."). When criticizing former decisions he includes himself using the pronoun "wir" (we), thereby indicating that he participated and has his share in former faults and failures: wi" $r$ haben außer acht gelassen * daß die satzung * da:s bisher nicht ermöglicht hat und wir haben auch außer acht gelassen * daß die satzung nur auf einer jhv geändert werden kann ("we disregarded that this was not possible according to the statutes and we disregarded that the statutes can only be changed by the decisions of a jhv"; jhv is the abbreviation for Jahreshauptversammlung, 
the annual assembly). The selfinclusion attenuates his criticism on former faults and makes it more convincing because he displays his ability of self-criticism.

\subsubsection{The dispreference for argumentative discussion and parliamentarian procedures}

One implication of Zehner's authoritarian manner is the dispreference for argumentative discussion, as the quotations above have already shown. In Zehner's social world, to discuss things that should be clear, is thought of as a waste of time; and it amounts to a general maxim to avoid this kind of discussions. ${ }^{15}$ This conviction is linked with the unwillingness to participate in a lengthened argumentation. Zehner's reactions to his opponents' argumentative resistance to his new norms and standards are: He either caves in without presenting any valid counterargument, or he reacts aggressively. His aggressiveness manifests itself in threats to take extreme legal action: wer diskutieren will soll des mit seinem anwalt oder mit dem arbeitsgericht tun ("who wants a discussion may do this with his lawyer or with the labor court").

Zehner's dispreference for parliamentarian procedures manifests itself in his disregard of formal rules; he mixes his political goals with formal procedures. When Vera demonstrates that Zehner's understanding of the statutes is formally incorrect, and makes an application which runs counter to Zehner's political goals, he fills the chairman's role - although Klaus is the assembly's chairman -, ignores Vera's motion, and turns to other presidential tasks. The assembly is shocked, and, motions having absolute priority, asks the chairman that the motion be dealt with immediately. His plans having failed, Zehner ostentatively styles himself as the loser, the assembly wanted him to be. Upon the call for the motion he reacts sarcastically: ja ich bin doch si "cher (daß wieder gegen mich gestimmt wird) * stimme mer $a$ "b- * ja: bitte handzeiche ** a"lso: mit überwiegender me:hrheit ("oh, I'm sure [that you'll vote against me again] * let's vote * put your hands up please * so by a vast majority"). He predicts the results of the vote, asks the assembly if he nevertheless should go ahead with the voting, and then he focuses on the results which confirm his predictions. He demonstrates, that he is aware of the assembly's negative verdict on him, that his defeat is predictable to him, and that therefore voting is unnecessary.

In contrast to Zehner, Klaus' communicative behavior is characterized by the preference for argumentative discussion and for parliamentarian procedures. Like most of the opponents he follows the academical democratic paradigm of "ausdiskutieren" (to discuss things thoroughly). So he meets the assembly's expectations when in his activities as a chairman he often uses formulations like "we have to discuss this point". And he submits without hesitation to the parliamentarian rules. After his opponents having changed the status of the assembly to 
a simple meeting, he adjusts very quickly to the new situation without any bitter comments on the defeat of the board's goals. Motions against the board's interests are handled businesslike and without any side-attacks.

\subsection{The implicit and indirect conflict management}

The preference for implicit and indirect conflict management is part of the rules of speaking in the social world of the Filsbach (Keim 1995b, Chap. 3.2). In the presence of an offender the cause of the conflict is not overtly named but only alluded to (by teasing, irony, sarcasm, etc.). Only the negative emotions the offense had arisen are to be shown to the person who committed the offense. But in gossip when the offender is absent, the cause of conflict is revealed, the offender is talked about explicitly and his actions are negatively evaluated. Gossip is an important device for criticizing the deviant behavior of others; it functions as a means of social control. Thereby, it is assumed that the offender gets to know the criticism and, as a result, is going to change his behavior. This is a very facesaving way of conflict management in a social world where people live in close spatial proximity and in close networks.

This general preference for indirectness in conflict management is reinforced in the actual situation, because the conflict is to be dealt with in public in the presence of outsiders, that is of newly recruited persons who are not yet insiders. In Zehner's perspective, acting in "public" prevents the disclosure of the crucial points of an insider conflict. Contrasting to this is his opponent's concept of the "public": for them the public is the guarantee for the maintenance of formal procedures in coping with a conflict situation.

\subsubsection{Allusions to the cause of conflict}

One of Zehner's goals is to bring about a management change because he thinks to have substantial indications of mismanagement. But he does not name the crucial points, and he does not give facts that could prove his suspicion. He only intimates that there is something at stake, and that he is going to reveal it later on. But nevertheless, he uses the facts he is only hinting at as a reason for his activities against the manageress.

Allusions are performed either by semantically week terms, so-called proforms, together with phonological and/or prosodic cues indicating that there is a 'second meaning'; or allusions are performed by periphrastic formulations that focus on background conditions. Right at the beginning of his first speech Zehner hints at the special significance of some items of the agenda: $s$ werdde hier einige the: "men diskutiert werden * abber zunäggschd muß etwas geklärt werdden ("Some themes are going to be discussed * but at first we have to clarify something"). The underlined sequence is for a long time the only formulation of the 
crucial point. The importance of these "themes" is indicated by stylistic variation: slower tempo, stretching of the vowel and strong accent in the focused element, and shift to standard German phonology (see the underlined sequence). In the variational paradigm of the "Filsbach" population, this cluster of linguistic markers signals that the things referred to are of high importance and - in the actual context - are to be expected to be the crucial points of the agenda. Even when the argument has fully arisen, Zehner does not name the crucial point but uses the same type of allusion: isch bitt alle mitglieder des vereins jetz ga " $\mathrm{nz}$ genau“ zuzuhöre ** wenn wir die:"sen punkt diskutiere- ** dann wäre es <se"hr> unratsam * wenn uns jemand hört * der uns bis jetzt nicht intern kennt ("I ask all the members to listen to me now, when we are going to discuss this point it would be very unfortunate, if people are present that don't know us well"). Here, the proform "this point" is combined with a phonological shift to standard German, with stress on and lengthening of the vowel.

In the next example, Zehner uses periphrastic formulations to refer to the special quality of the crucial point: <das ist hier und heude koine midgliederversammlung * sondern eine au"ßerordentliche jahreshauptversammlung * bei der interna des vereins zur diskussion gestellt werdden> * wobei denn neu"e mitglieder die heu"te neu" hinzukommen * öh* schon aus dem grund weder midsch/beschdimme noch midabschdimme könne * weil sie die"se dinge aus eigener sa"chkenntnis * gar nischd wissn könne * und gar nischt wissn mï"ssen ("today, this is not a normal meeting but an extraordinary general meeting where "interna" of the association are going to be discussed; newcomers should not deal with these things because they neither can nor have to know them"). At first, Zehner focuses on the special state of the meeting by stressing the term au"ßerordentlich ("extraordinary") and by using a "not - but" format, where the "but"-sequence contains the highlighted expression. The term außerordentliche jahreshauptversammlung indicates a meeting where only special and severe problems are to be dealt with. Zehner refers to these problems as "interna of the association that newcomers should not know". The exclusion of newcomers indicates, that the "interna" are extremely delicate and should not be unfolded to unprepared "freshmen". The presence of these reinforces his preference for indirectness and implicitness, and prevents his disclosing the crucial points throughout the whole meeting.

After the manageress' having disclosed her business practices (she admitted their having been not always according to the rules, but she had done it to the association's advantage, and the former board had known about it), she asked Zehner for precise details regarding his allusions to mismanagement. Even then Zehner does not disclose any facts; instead, in an outrageous speech, he accuses 
her of "criminal practices". From the opposing participants' point of view, Zehner passes sentence on her without having given any facts that would justify this severe accusation.

\subsubsection{The ironic and sarcastic speech modality}

Zehner very often uses an ironic or sarcastic speech modality when he intents to expose and to ridicule his opponents' actions. This evokes their protest and rebellion. In order to prove that Zehner's new work order already had done damage to the association's reputation, one of the opponents reads the protest letter of a foreigner group. So far, this group had the opportunity to use the association's rooms for their cultural activities; now, as a result of the new work order, the rooms couldn't be used any more. The letter is a complaint about the fact that the group has nowhere to turn to, and feels isolated. The letter's whole style and especially some formulations leave the impression that it was written with the speaker's support and in his own interest. Zehner reacts ironically: zunäggschd freu isch misch sehr darüwwer wie elegant unsere laotischen freunde auch schriftlisch formuliere könne ("I'm very happy to hear that our laotic friends are so very sophisticated in their formulating and writing a letter"). His irony aims at the letter's style, which he doesn't recognize as the laotic group's style but - this is insinuated by his irony - as the style of his opponent, who used the laotic group's name for his own purpose. His irony fails. His opponents fall back on the possibility to take the ironic utterance literally, and denounce it as elende diskriminierung von ausländern ("a terrible discrimination of foreigners"). The manageress' outrageous reaction on Zehner's irony highlightens the kind of stylistic divergence being at stake: oh wa "lter >jetz sprech doch ei "nmal ehrlich* einmal möcht ich mit dem vorstand ehrlich sprechen können * mein gott noch mal ("my god, Walter, why can't you be frank and honest; only once I want the president to be honest and frank with me"). The point of her severe criticism is that she shows Zehner the inadequacy of his communicative social style, and she indicates that his indirect way of conflict management is to be understood as a lack of honesty and frankness.

\subsubsection{Socio-symbolic variation}

In the social world of the Filsbach, one of the most effective ways to characterize and evaluate other people indirectly is the socio-symbolic linguistic variation. ${ }^{16}$ The characterization of other people as, for instance, "strange" and "unpleasant" is brought about by the way a speaker lets them talk and by the kind of language he lets them use. The special way of putting a person into limelight indicates the kind of social category the speaker attributes this person to. ${ }^{17}$ In the following example, Zehner indicates the negatively valued social category to which he re- 
lates his opponents by the special way of quoting their reactions to his new work order: und hier hat man allen ernstes zu mir gesa:gd * wortwörtlisch * die bedï"rfnisse: * der mitarbeiter in jeder hinsicht auch in kulture"ller * die müßten bei der aufschdellung des arweidsplans zunä: "gsd berïcksichdigd werden < $a$ "nschließend * eh * >die bedürfnisse des veroins * uff monnemerisch * also i"sch leg moi aaweidszeid feschd wie mir=s baßt ("and they said to me, very earnestly, and word by word, the needs of the employees in every respect, especially in cultural respect should be considered before planning the new work order * after their needs being taken into account the needs of the association could be considered, too* a Mannheimer would say I fix my working hours just as I please").

Zehner cites his opponents in an exaggerated German standard, with the pronounced articulation of syllables, especially the end syllables, the softening and voicing of the unvoiced alveolar fricative $/ \mathrm{s} / \rightarrow / \mathrm{z} /$ as in anschließend and müßden, the lengthening of short vowels as in bedü: "rfnisse and zunä: "gsd. In Zehner's sociostylistic paradigm this kind of exaggerated standard is used for the caricature of a special social category, that is a person accentuating his/her better social status in contrast to his/her partner's, and behaving arrogantly. The lexical items "Bedürfnisse" (needs/wants) and "kulturelle Hinsicht" (cultural respect) in the opponents' quote are not characteristic for Zehner's 'normal' language; they signal that the cited speakers belong not to Zehner's own social world but to a social world which they think to be a better one. Their demand on the president is characterized as based on the reverse of the normal role-constellation between employer and employee; the employees dictating the employer the conditions for the new work plan. Thereby, they are presented as highly impudent. Quoting his opponents in this way, Zehner expresses symbolically that he thinks they believe him to be socially inferior and incompetent.

Then, Zehner translates his opponents' demand into his own speech style. This is signaled by the comment uff monnemerisch ("a Mannheimer would say") and a shift to dialect: monophthongization in uff (std. "auf") and monnemer (std. "Mannheimer"), velarization and nasalization of the diphthong /ei/ $\rightarrow$ /õi/ as in moi (std. "meine"), dentalization of the bilabial plosive $/ b / \rightarrow / w /$ and vocal assimilation of the $/ r /$ as in aaweid (std. "Arbeit"). Compared with the opponents' quote the meaning of the translated sequence has changed; here, Zehner expresses explicitly that he thinks his opponents' elaborated style is nothing but a way of concealing their arbitrariness and their unwillingness to work ("I fix my working hours just as I please"). The socio-symbolical variation is a very sophisticated way of expressing indirectly one's evaluation of other people's behavior and of typifying their actions as those of negatively valued social categories. 
Zehner's characterization of his opponents is met by the audience's protest. He rejects this protest by stating that he did nothing but quote the employees' speech (so" wurde es gesagt un jetz hab isch das wort, "this is what had been said, and now it is my turn"). The advantage of this characterization by sociosymbolic variation is that it is difficult to put any claims on the quality of the characterization; it can't be negated and it can't be worked on argumentatively. In the paradigm of people from an academic milieu this discoursive pattern is dispreferred as being of bad style and belonging to the uneducated.

\subsubsection{Divergent styles of conflict management}

To sum up, in his acting in a situation of severe conflict Zehner obviously falls back on the type of conflict management familiar in his own social world which is characterized by indirectness, not-explicating of presuppositions and maxims, the apodictic setting of norms and standards, and the sociosymbolic characterization.

That the Filsbach way of conflict management is a very effective and economically functioning system will be demonstrated in the following example. In his own social world, Zehner succeeds in his way of conflict management. At the meeting of a "Mieternotgemeinschaft" (association of exploited tenants), where he is president too, Zehner acts very effectively. The goal of the meeting is to disclose severe manipulations of a powerful house-building society, and to plan counteractions. At the start of the meeting, Zehner establishes himself as the speaker of the sufferers - ordinary people as he himself - , and he turns massively against the powerful; thereby he sets norms and standards presupposing their generality, attacks the powerful, and exposes their failures in the same indirect manner as he did in the case of the employees (allusions, sarcasm, sociosymbolic variation). Here, he succeeds in getting a vast majority for his plans and for his intended counteractions against the powerful. This means that in this role, as one of the crowd or so to speak as primus inter pares, Zehner's Filsbach style is very effective in claiming common ground. In the community center, Zehner is culturally on "foreign territory"; and he lacks the support of his own cultural group.

Zehner's type of conflict management contrasts extremely with the type preferred by most members of the association, especially their preference for thorough discussion (see above, 2.2.3.) and for criticizing in a direct way. In contrast to Zehner, Klaus' ways of criticizing are frank and direct; he reveals his intention mit offenen Karten zu spielen und klare fakten zu nennen ("to put my cards on the table and to name clear facts"); he names the source of information his criticism is based upon, so anybody can check on the seriousness of his criticism; and he demonstrates that he is fair in coping with first- and second-hand information. 
Furthermore, he reveals a very personal motive underlying his commitment to the board: It was his suffering under the constant disorganization and the painstaking cliquism that brought about his conviction that a new work organization will be the only means to overcome the present crisis. By revealing his intentions and motives he increases the credibility of his actions and makes his proposals comprehensible. Furthermore, he demonstrates his ability to self-criticism. On one of Vera's objections he admits having already committed faults as member of the board: des stimmt ja [was du sagst] * da ham=mer uns geirrt ("you are right here, and we were mistaken").

Zehner knows this other type of communicative behavior quite well: As a member of the association he already had the chance to get familiar with the other members' communicative style. In an interview, he reveals his experiencing the stylistic differences, and he evaluates the others' behavior partly critically, and partly amused. Furthermore, before his election, he had already demonstrated that he is quite able to cope with the sociostylistic difference; he very effectively knew how to deal with the academically trained members of the association. In the actual conflict situation, however, Zehner ignores systematically the sociocultural differences.

\section{The Work of Perspectivation}

The observed ignoring of rather well-known cultural differences is part of a handling perspective differences which leads to a mutual exclusion of standpoints. From the very beginning, both parties display opposing perspectives on the association's present state and on its work organization. Each party assumes to know very well about the strategically hidden intentions of the other, and to be certain about the decisive features of the other's perspective. Each party rejects the opposing perspective on a subject matter as inadequate, and both parties mark very clearly that the own perspective is unchangeable. This is a rather common trait of an antagonistic argumentation which we will characterize in terms of a theory of perspectivity in verbal interaction. ${ }^{18}$

Very generally, all human beings' perceiving and acting is done from a specific viewpoint which, together with the scope and other structural characteristics of perspective, determines the space of perception and activity. All objects are perceived and interpreted in those aspects that correspond to the given viewpoint and perspective. In verbal interaction, the taking into account of the other's perspective, at least up to a certain extent, is a constitutive precondition in order to establish an interactive exchange. ${ }^{19}$ As a consequence, verbal interaction is - on a certain level - structured as a process of perspective setting and perspective taking (see Graumann 1989). Perspective setting means that in order to make 
one's actions comprehensible and to enable others to deal with one's perspective, a speaker has to reveal his/her perspective, at least up to a certain extent. Perspective taking means that recipients have to show how they interpret the manifested perspective, how they relate their own perspective to it, and to what extent they adopt the speaker's perspective, or incorporate it at least partly in their own. Perspective setting implies a claim of social relevance for the manifested perspective, and perspective taking deals with this claim. Both parts of perspective work constitute a process of negotiating common ground. The mutual revealing of perspective and of relating one's own to the other's is an important part of "participant's work" in verbal interaction. ${ }^{20}$ We will call it "perspectivation".

Our analysis of perspectivation in the conflictual interaction starts with the following questions:

(a) To what extent does a speaker reveal his/her perspective, and how explicitly or implicitly is this done? We concentrate on forms and functions of explicating perspective, and on the relation between implicitness and conflict dynamic.

(b) Are others' perspectives taken into account, and how is this achieved? In this respect, we will analyze a characteristic loss of flexibility in perspective taking.

\subsection{Explicitness and implicitness of perspective setting}

There are various verbal practices for the manifestation of a particular perspective. A most striking way is the framing of a statement with an explicit formulation of the speaker's actually held perspective being at the root of his/her statement. Explicit perspective framing recurrently uses expressions like "standpoint", "viewpoint", "position", "opinion" and expression for perceptive or cognitive orientation together with personal deixis (or reference when attributing perspectives to third persons). These formulations refer to the relevance of a certain perspective and attribute it to a social unit. As there exists a rather strong link between the habitual perspectives attributed to persons and their social categorization, the specificity of a perspective is very often expressed by explicit social categorization like "I as...", "in my capacity as" or "in my quality of...". The reference to a perspective by identifying its "owner" may be done in more or less expanded descriptions too, like "my family lives here since ninety years", indicating the quality of being "local".

Perspective framing is a powerful contextualization device which links an actual utterance to a whole background of information about the speaker's social identity, his/her actual and habitual social roles and his/her criteria of relevance, and so provides for the possibility of a deeper and appropriate understanding of the utterance. In verbal interaction, explicit perspective framing appears sys- 
tematically in certain contexts: When the identification and differentiation of various perspectives or positions becomes necessary; when the explication of participants' specific orientations and backgrounds becomes relevant in order to prevent misunderstandings; and when, in controversy, participants characterize their statements as not ad hoc and ephemeral, but essential for their claim.

In our case, Klaus realizes several times perspective framing. In the following example, he explicates that he is arguing from the board's perspective: aus unserer sicht empfiehlt es sich * daß die neuen heute nicht anwesend sind ("from our viewpoint it might be recommended that newcomers should not be present at today's meeting"; "our" refers to the members of the board). In another example, he combines two different perspectives. First he presents his personal experience as somebody who was suffering from the former chaotic work conditions and the personal hostility among the staff of the community center; this perspective is related to the use of the personal pronoun "I" (ich). Then he shifts to a "we"-perspective and argues in his role as member of the board (wir als vorstand) who has the power to change these conditions: hier gab=s immer sündenböcke ich war auch mal ein sündenbock * als ziwi hier ne zeitlang (...) das is ne masche * die wir als vorstand nicht mehr tolerieren ("always, there is somebody made a scapegoat, me too, I was made a scapegoat in my time working as a ziwi (...) that is a trick which we as members of the board won't tolerate anymore").

Generally, in order to claim social relevance speakers establish an epistemic modality of certainty by expressing a firm conviction, and indicating competence and responsibility. In Klaus' utterances, this latter aspect is realized by the reference to personal experience for the "I"-perspective, and to the official role for the "we"-perspective.

In his role as president, Zehner too, makes his perspective explicit when grounding his actions and decisions on the association's statutes and rules. For example, when he criticizes a former decision he explicitly marks his presidential perspective as legally grounded: der ausschlu $\beta$ [eines Mitgliedes] erfolgte * öh auf einer norma"len midgliederversammliang * <die nach satzung und geschäfdsordnung $\leftarrow n u$ " $r$ dara: " $n \rightarrow$ werd isch misch halde * [den Ausschluß niemals hätte beschließen dürfen] ("the expulsion [of a member] was decided in a normal meeting where according to the statutes and the rules which are my sole guidelines for action [it should not have been decided]").

But in the essential argument about the new work order, Zehner does not reveal the ideas and maxims his perspective is based upon, and he does not frame his perspective explicitly as deeply grounded in his own social world. His ideas of organizing work orientate towards the paradigm of industrially organized 
manual work where the out-put is concrete and the worker's efficiency is computable and quantifiable. Zehner discloses this orientation in a private interview but he does not disclose it in the conflict with the employees. He does not explain what he thinks to be the advantage of his organizational paradigm over the present work organization, and he does not reflect upon the applicability of his model to academical and socio-pedagogical work. For example, he states that working by regular and exactly fixed working hours is the only way to guarantee an effective and prolific work (eine überschau"bare und fru"chtbare arweid), thereby presupposing that the orientations familiar in his own social world are naturally shared by the employees as well. But the employees establish a clear contrast to him; upon his statement isch bin also da "für * daß ma hier * ga" $n z$ norma "le aaweidsbedingunge schaffd und die je:der donn oinhäld ("my opinion is that we should establish quite normal work conditions that everybody has to respect"), they react ironically norma "le genau ("normal conditions, exactly"), and they contrast their ideas of 'normality' to Zehner's.

The employees' concept of work as it transpires from their statements aims at the negotiation of a work's substance and goal as well as the right of selfdetermination in realizing these goals. Their daily work contains so disparate tasks as individual advising, actual help for people in an emergency, the planning and carrying-out of cultural and recreational activities. These tasks are not computable, and most of them have be to decided upon ad hoc. To do this kind of work effectively, a high personal commitment is required as well as a vast amount of flexibility, and constant cooperation with others is needed.

So, Zehner who frames his perspective explicitly when grounding his position on formal regulations, does not account for the culturally based divergence of the opposing parties' work concept, even so he knows the differences quite well. In this argument, he grounds his position on knowledge which he takes for granted, and he uses an implicit but nevertheless very directive way of claiming common ground. The force and the conflict increasing potential of this discourse practice is based on its implicitness (see above, 2.3.): the common ground and the claim of social relevance are presupposed or are referred to by allusions - one has to know it if one wants to pass as a competent member of society.

The employees are more explicit in perspectivation. They characterize Zehner's presenting the new work organization as es sind dienstpläne ausgehändigt worden * und- * es gab kei"ne inhaltliche befragung es gab überhau"pt noch kein gespräch nach welcher richtung die arbeiten hier ausgerichtet werden sollen ("new work schedules were delivered to us and we hadn't been consulted, and there never had been any exchange of ideas about the future orientation of our work"). They interpret the new work organization as an 
encroachment upon their pedagogical concept because it was worked out ohne absprache mit uns * ob es überhaupt sinnvoll und notwendig is * aus pädagogischen gründen und * von u"nserer erfahrung her ("without consulting us if the new organization does make sense, and if it is necessary for pedagogical reasons and according to our experience"). And they complain about the president's ignoring their competence and their work already done. Then they outline their unauthoritarian model for a president's way of acting which contrasts extremely with Zehner's behavior: A president should be sensitive and he should ask his employees for information about their work; he should take interest into their problems and be cooperative.

Throughout the whole argument, the basic discourse practice on the employees' side is to explicate their perspective by contrasting it with Zehner's. This is a form of taking into account others' perspective, an operation which can be done in various ways, depending on the attribution or denial of social relevance to it. In our case the employees use a common topos of argumentation in order to exclude Zehner's perspective from the range of the socially relevant ones. It is a specific variant of the Aristotelian topos of manner which can be paraphrased as "I was ready to do the right thing, and I would have done it if you would have asked me for it in the right manner". The employees state that they were ready for changes in the management and in the work organization; but they experienced Zehner's behavior as aggressive and as disregarding and devaluating their professional competence in such a way that it had to be considered as destroying the basis for further cooperation. This is a strong indication that they exclude Zehner's perspective from further consideration.

\subsection{Taking into account or ignoring the other's perspective}

So far, our analysis already gave some hints to non-cooperative ways of dealing with the other's claim of social relevance of their perspective. These aspects of perspectivation will now be considered in a more systematic way.

Conflictual interaction leads participants to view things fundamentally; they seek a deep grounding of perspective in basic convictions and in cultural beliefs taken for granted. The deeper a perspective is grounded, the stronger is the claim of its social relevance. The analysis shows the existence of at least two contrary strategies of "being fundamental". One is claiming common ground, e.g. putting forward common interests that should dominate the actual divergence of opinions. This is a means of constructing a common perspective. The opposite strategy may be called "claiming exclusive ground"; that means that the speaker is sure of the relevance of his own perspective, but that he has strong doubts about the other's ability of perspective taking, or that he even presupposes the other's inability of it. This is what Zehner and the employees are doing in different ways. 
Claiming common ground is part of a rather cooperative way of interacting where a mutual assimilation of perspectives takes place, or where the participants explicitly incorporate divergent perspectives into an overarching one. In our example of conflict talk, this latter practice of perspectivation is realized by some of the less involved participants of the assembly, but they don't succeed with their initiative to change the antagonistic character of the argument.

Klaus, too, shows some flexibility in coping with divergent perspectives. Contrary to the employees' practice analyzed above, he takes into account the other's point of view, its right and its legitimacy, even though he does not adopt it. At the crucial point in the argument for instance, when the whole meeting is at stake, he acknowledges Vera's view on a legal point at issue, and proposes that the different legal interpretations should be checked by a lawyer: also (...) wir sin keine anwälte * wir ham beide en rechtsverständnis des is unterschiedlich * und da kom $=$ wer auch zu keiner einigung * höchstens es is $=n$ rechtsanwalt da der in der lage is dieses zu entscheiden ("we are both no lawyers, and we have a different conception of legality, and with this we can not get to an agreement, except there is a lawyer who is able to decide on this"). With this proposal he induces his opponent to cooperation: After having acknowledged the legitimacy of her viewpoint, Vera accommodates towards him presenting a pragmatic solution, a compromise on which they can continue with the meeting without a lawyer's help. In another case, Klaus agrees with a statement of the opposing side, demonstrating that he is willing even to adopt his opponents' view if it is well founded. Klaus's way of dealing with perspective divergence implies a reference to a common ground which is a concept of democratic procedure and political negotiation.

Nevertheless in our case, claiming exclusive ground is the prevalent practice of perspectivation. On the whole, the interaction is characterized by the protagonists' concentrating on their own perspective and by excluding the others'. That is, they assume to know the other's view but they don't give any consideration and any weight to it. The holding on one's own perspective in accordance with the attempt to carry it through brings about a "monoperspective" way of participation almost throughout the whole interaction.

Generally, there are different verbal practices for arguing in a monoperspective way. There are smoother and more persuasive verbal practices, whose main features are: taking the other's view into account, relating it to one's own view, considering and demonstrating the advantages of one's own perspective over the other's. Harsher forms comprise the ignoring, the demeaning, the caricaturing or the spurring of the other's perspective. Harsher forms usually result in the opponent's protests and in his rejecting the procedure. As a consequence, the opponent 
often seals off his own perspective; that means, his understanding others activities is reduced, sometimes to the point of not listening anymore, and he renounces any cooperativity in rational reasoning.

Zehner practices almost exclusively harsh forms of monoperspective reasoning. In the following example, he contrasts his view on a subject matter with the decision of the former president Vera; thereby he presupposes that her view was wrong and that she even made a decision against the statutes: isch bin aber auch nischt bereit daß die"ser vorstand an sa"tzung un geschäftsordnung vorbeihandeld * wenn das unter deiner vorstandschaft liebe Vera * a"nders gehandhabt wurde * dann tut es mir leid das hast du" nischt $i$ "sch zu verantworte ("as a president I'm not prepared to act against the statutes and the rules, if you, my dear Vera, acted in this way as the former president, it is deplorable; you are responsible for that and not me"). Assuming that the former president ignored the legal basis he devaluates her actual statement as legally unsound, and he discredits her as a competent partner in an argument.

In the following example, Zehner's rude monoperspectivity leads him to overt aggressiveness: When the former president criticizes the board's handling of the discussion, he rejects her criticism as unfounded because of her generally lacking juridical knowledge, presupposing that he himself is right on this point: dann hosch du wie "derum dei satzung net im kopf * des hab isch schon leider öfter festgestellt ("there, you don't know the statutes and the rules; this I noticed already many times, and it is deplorable"). When she states that she had checked the validity of her statement, Zehner does not withdraw his reproach; instead he tops his former aggression by implying that her check is irrelevant because she never had read the statutes and the rules, not even as a former president. With this he completely denies her any competence, claims the irrelevance of her view, and very severely threatens her face as former president.

The last stage in perspective inflexibility is sealing off one's perspective. Thereby, the actor dramatically reduces not only his perception of the other's perspective but he even stops perceiving the other's activities. One of the consequences of this perspective narrowing is that the actor commits errors to his own disadvantage.

At least once, Zehner shows a definite sealing off his perspective when persistently demanding a proof for something which is evident to everyone: When Vera demonstrates that Zehner has committed a formal error (she asserts that he didn't invite within the specified time, and that therefore the status of the conference had to be changed; she proves this by showing the postmark of the invitation), Zehner rejects that statement as eine blanke behauptung ("as a pure conjecture") and asks her for proof. This proof, however, had already been given. 
The practices of perspectivation, we presented so far, result in reducing the possibilities of perspective taking and of constructing a shared perspective. Monoperspectivity may be a rational and very successful discourse practice. But in severe controversy, it has a strong potential for claiming exclusive ground, and for losing sight of the possibility to construct a common perspective.

\section{The Interaction Modality of a "Social Drama" and the Ideology of "Correct Style"}

The observed practices of claiming exclusive ground get their specific force by two elements: first, each party's idea to have exclusively the "correct style" the main point of the communicative ideology on both sides - and secondly, the demonstrative accomplishment of this style; participants show that all their acting is deeply rooted in one's own culture and following fundamental principles.

The opposing parties' following such a fundamental orientation is, at first, not openly manifested, but in the course of the meeting the debate develops into an open discussion about divergent cultural paradigms. The quality of the argument as fundamental is reinforced by the protagonists' not only speaking for themselves but grounding their positions on general principles which are related to the goals of the association as an urban institution.

The most striking discourse practices constituting an interaction modality of fundamentally speaking are:

(a) Long statements whose importance is signaled by introducing formulations like: ich möchte grundsätzlich was dazu sagen ("I want to say something fundamental to that").

(b) Reference to fundamental tasks and goals of the speaker's work, i.e.: ziel mei "ner arbeit ist (...) im interesse der $k i$ "nder * und der eltern (...) für die integration in diesem stadtteil tätig zu sein ("in the interest of the children and their parents, my work's object is to engage for the integration [of foreigners] in this district"); es ist nicht nur mein recht sondern auch meine pflicht ("it is not only my right but my duty"); wir sind angetreten [um mißstände zu verbessern] die $=s$ so nirgends auf der welt gibt ("we see it as our duty to reform the serious shortcomings that exist and which can not be found in any other part of the world"; the German construction "antreten um zu" has the connotation of putting one's whole energy into the task); wir wollen bestimmte grundsätze wieder herstellen (...) grundsätze die verletzt worden sind [und] die ner gruppe zu eigen sind ("we want to reinstate certain principles (...), principles which were violated and which are the constituting elements of a group").

(c) Reference to deeply grounded maxims, i.e.: nur wer erfahrung sammelt kann sinnvolle veränderungen schaffen ("only he who is able to make experi- 
ences is able to change things in a sensible way"); das widerspricht der grundkonzeption des vereins ("this contradicts to the fundamental idea of the association"); wir wollen nichts subjektives * wo ihr vorstand seid habt ihr verantwortung für den gesamtverein ("we don't want anything subjective, you as the board are responsible for the whole association"); oberste maxime für uns ist offenheit und direktheit ("our most important maxim is openness and directness"); [the board's decisions] werden nicht nach sympathien [erfolgen] sondern nach der sache ("will not be grounded in sympathies but they will be oriented towards the subject matter").

(d) Reference to strong moral feelings when criticizing others i.e.: das hat mich sehr sehr betroffen gemacht ("I was really deeply dismayed by this"); [assessing the behavior of the opponent as] mehr als eine beleidigung ("more than insulting"); [the reproach that others] werden ausgeschlossen und $z u$ sündenböcken gemacht ("are excluded and are made scapegoats").

(e) Explicit positive selfpresentation as a moral and responsible actor, i.e.: isch bin ein mann des kompromisses [und ich bin] nicht der mann der eine partei gegen die andere aufhetzt ("I am the man ready to compromise and I am not the man to incite one party against the other").

This attitude of grounding one's position on general principles reminds us of V. Turner's concept of the "social drama" (Tumer 1975). In accordance with this concept, when social conflicts are intensified, the actors, presenting different social groups and their interests, carry on the differences between their groups in a direct verbal argument, thereby demonstrating different cultural paradigms which sometimes are expressed symbolically; and they compare their power. In our case too, both parties attach to some features of their respective conflict management a high symbolic significance, and they describe these features in sociostylistic categories. When the employees, reacting on Zehner's harsh monoperspectivity, describe their complete turning against him, they call his incompetent communicative style the main reason for "setting up a wall": es war die form und die art und weise wie" die veränderung vorgebracht wurde * die also von u"nserer seite her da eine mauer aufgebaut hat ("it was the form and the manner of presenting and carrying through the changes that brought us to set up a wall"). As a counter-move, Zehner too recurs on stylistic categories. He characterizes his opponents' behavior as the arrogant and impudent behavior of persons of a higher social status towards a person in a lower one (see above, 2.3.3.)

The actors demonstrate their fundamental principles within their actions; there is no difference anymore between the stated principles and the action itself. This specific reflexivity is brought about by an intensified "documentary interpretation" 21 - concrete actions are seen as typical of a specific pattern - and by 
using widely a specific argumentative topos, the topos "to start with one's own behavior"; that means, one has to follow the propagated pattem oneself before criticizing other people, or giving them orders.

The deep grounding of one's actions in a cultural paradigm and in sociostylistic deeply rooted patterns gives these actions the power which is necessary to carry things through. This is particularly important in situations which are elementary for the manifestation of one's social identity and its differentiation from others'. But this interaction modality possibly enforces and increases a negative dynamic in a conflict situation; and participants start claiming exclusive ground when they assume that there is no chance of getting others to adopt their deeply rooted perspective, and to accept it as relevant. They get involved up to a certain state where they can't change anymore their ways of acting without jeopardizing their credibility and their social identity. This attitude of "here I stand, I can do no other" excludes verbal practices typical of rational negotiations; and the symbolic highlighting of one's actions - in our case by stylistic categories enforces the inflexibility in negotiating. Thereby processes can be triggered that lead to catastrophic results like schismatic processes, the expulsion of others, the self-exclusion from the actual social unit, or even forms of self-sacrification.

\section{Notes}

1 For a detailed description of our ethnographically based sociolinguistic study of different social worlds in the city of Mannheim, see Kallmeyer (1994).

2 For a definition of our concept of communicative social style, see Kallmeyer (1995); for a description of the communicative social style of specific social worlds in Mannheim, see Keim (1995b) and Schwitalla (1995).

3 See for instance Heath (1983), Moerman (1988), Tannen (1984), Willis (1981).

4 See for instance Ervin-Tripp (1972), Kallmeyer (1995), Labov (1972), Levinson (1988), Sandig (1986).

5 For the detailed ethnographic description of this inner city area of Mannheim, see Keim (1995a). The official name of this city area is "Westliche Unterstadt", the folk name is "the Filsbach". People living in this area are called "the Filsbacher". This area is a traditional area of the working class people mixed with lots of foreigners who came in the sixties and seventies. At this time, the urban renewal program for this area was starting too.

6 For a review of different theories on miscommunication in interethnic situations, see Streeck (1985).

7 "Interaction modality" is a translation of the German term "Interaktionsmodalität" which denotes a set of interpretive procedures by which a specific symbolic meaning is attributed to a 
representation, action or situation relating to special domains of meaning, such as "dream", "play", or to participants' epistemic state. Our concept is based on A. Schütz' concept of the "finite provinces of meaning" (1962-66, II:230-259, 340f) and E. Goffman's concept of "frame" (1974). In grammar and logic , the term "modality" normally refers to the framing of propositions whose relation to reality is defined by expressions like it is possible that or I believe that a.s.o. The concept of interaction modality takes into account that the modal framing can cover interaction structures of various degrees of complexity, from single utterances or parts of utterances to whole activity complexes. Interaction modalities framing activity complexes usually are announced and negotiated at the activity's beginning. The change of interaction modality is marked by the speaker and ratified or rejected by the recipient; this is manifested i.e. by the recipient's laugh, a corresponding utterance or by his refuse. For an explication of the concept "interaction modality" see Kallmeyer (1979: especially pp. 556-557); see also Kallmeyer, Keim \& Nikitopoulos (1994). A similar concept of interaction modality in respect to conversational humor uses $\mathrm{H}$. Kotthoff, in this volume.

8 For a detailed description of the community center "Begegnungsstätte Westliche Unterstadi", its history and its activities, see Keim (1995a: chap. 4.2.2.1).

9 For a description of these patterns of variation practice, see Keim (1995b: chap. 4.2.2.2 and 4.2.3.2).

10 For our notion of the term "default stylistic level" and for various functions of stylistic variation, see Kallmeyer \& Keim (1994a).

11 For the transcription system, see Appendix on p. 298.

12 Seen from the viewpoint of an outsider, the typical "Filsbach tone" parents use when they talk to their children is "rough", "crude" and "coarse"; they don't argue but give simple commands and instructions; see Keim (1995a: chap. 4.1.1 and 4.2.2.1).

13 For this kind of marital constellation see Kallmeyer \& Keim (1994b); here, it is the wife who dominates the husband; the typical behavior of the wife - as it is displayed by the Filsbach speakers - is that "she commands him" and "controls him", and "she gives the orders".

14 In associations, the position of the president is dominant; in association meetings, it is the president who gives orders and instructions, and there are almost no discussions about presidential decisions. Criticism is only mentioned in side-activities or in gossip about the president; see Keim (1995a: chap. 4.2.2.2).

15 In interviews, the Filsbach population often complains about the "endless discussions about nothing" which they perceive to be the normal behavior of the academically trained members of the community center. For one of the interviewees who at first was very interested in the association's work, this preference for discussions was the main point which kept him off the association.

16 Our concept of socio-symbolic linguistic variation is influenced by Blom \& Gumperz concept of the "metaphoric code-switching" (1972). For a detailed description of our concept and a detailed analysis of the variational practices and the constitution of social meaning, see Kallmeyer \& Keim (1994a).

17 Our notion of a "social category" is influenced by Sacks (1972) and (1979); for a detailed analysis of the process of categorization in discourse, and for a survey of verbal practices for constituting social categories, see Kallmeyer \& Keim (1994c); for the relation between linguistic variation and social categorization see Kallmeyer (1989) and Kallmeyer \& Keim (1994a).

18 Our theory of perspectivity in verbal interaction is outlined in an unpublished paper "On perspectivity". Mannheim 1994.

19 In interaction theory, perspective taking in verbal interaction up to a certain point is seen as one of the basal rules in order to achieve mutual understanding in regard to situational requirements; see e.g. Garfinkel (1967).

20 See Jefferson (1972).

21 See Mannheim (1952:57); Garfinkel (1967:78). 


\section{References}

Barth, F. 1969. "Introduction." In: F. Barth (ed.), Ethnic Groups and Boundaries. Oslo, 9-38.

Blom, Jan-Peter \& John Gumperz. 1972. "Social Meaning in Linguistic Structures: Code-switching in Norway." In: John Gumperz \& Dell Hymes (eds.), Directions in Sociolinguistics. The Ethnography of Communication. New York, 407-434.

Ervin-Tripp, Susan. 1972. "On Sociolinguistic Rules: Alternation and Co-occurrence." In: John Gumperz \& Dell Hymes (eds.). Directions in Sociolinguistics: The Ethnography of Communication. New York, 218-250.

Garfinkel, Harold. 1967. Studies in Ethnomethodology. Englewood Cliffs, New Jersey.

Goffman, Erving. 1974. Frame Analysis. Harmondsworth.

Graumann. Carl. 1989. "Perspective Setting and Taking in Verbal Interaction." In: Rainer Dietrich \& Carl Graumann (eds.), Language Processing in Social Context. Amsterdam, 95-122.

Graumann, Carl, F. \& Michael Sommer. 1988. "Perspective Structure in Language Production and Comprehension." In: Journal of Language and Social Psychology 1988. Vol. 7/3-4, 193-212.

Gumperz, John. 1978. "Sprache, soziales Wissen und interpersonale Beziehungen." In: Uta Quasthoff (Hg.), Sprachstruktur - Sozialstruktur. Kronberg, 114-127.

Heath, Shirley Brice. 1983. Ways with Words. Language, Life, and Work in Communities and Classrooms. Cambridge.

Jefferson, Gail. 1972. "Side Sequences." In: David Sudnow (ed.). Studies in Interaction. New York, 294-338.

Kallmeyer, Werner. 1979. "(expressif) eh ben dis donc, hein" pas bien' - Zur Beschreibung von Exaltation als Interaktionsmodalität." In: Rolf Kloepfer in Verbindung mit Amold Rothe, Henning Krauß \& Thomas Kotschi ( $\mathrm{Hg}$.), Bildung und Ausbildung in der Romania. Bd. 1 Literaturgeschichte und Texttheorie. München, 549-568.

Kallmeyer, Werner. 1989. 'Wir und die anderen. Sprachliche Symbolisierung sozialer Identität und soziale Segmentierung." In: Peter Nolde ( $\mathrm{Hg}$.), Urban Language Conflict. Bonn, $31-46$.

Kallmeyer, Werner (Hg.). 1994. Kommunikation in der Stadt. Exemplarische Analysen des Sprachverhaltens in Mannheim. (Schriften des Instituts für deutsche Sprache, Bd. 4.1). Berlin - New York.

Kallmeyer, Werner. 1994. "Das Projekt 'Kommunikation in der Stadt'." In: Werner Kallmeyer (Hg.), 1-38.

Kallmeyer, Werner. 1995. "Zur Darstellung von kommunikativem sozialem Stil in soziolinguistischen Gruppenporträts." In: Keim 1995b, 1-25.

Kallmeyer, Werner, Inken Keim \& Pantelis Nikitopoulos. 1994. "Selbst- und Fremddarstellung im Gepräch und Regeln des Sprechens. Untersucht am Beipiel einer Stehcafé-Gruppe in Sandhofen." In: Wemer Kallmeyer (Hg.), 39-140.

Kallmeyer, Werner \& Inken Keim. 1994a. "Phonologische Variation als Mittel der Symbolisierung sozialer Identität in der Filsbachwelt." In: Werner Kallmeyer (Hg.), 140-249.

Kallmeyer, Werner \& Inken Keim. 1994b. "Formelhaftes Sprechen in der Filsbachwelt." In: Werner Kallmeyer (Hg.), 250-317.

Kallmeyer, Werner \& Inken Keim. 1994c. "Bezeichnungen, Typisierung und soziale Kategorien. Untersucht am Beispiel der Ehe in der Filsbachwelt." In: Werner Kallmeyer ( $\mathrm{Hg.}$.), 318-386.

Keim, Inken. 1995a. "Die Westliche Unterstadt." In: Werner Kallmeyer (Hg.), Kommunikation in der Stadt. Ethnographien von Mannheimer Stadtteilen. (Schriften des Instituts für deutsche Sprache, Bd. 4.2). Berlin - New York, 42-188.

Keim, Inken. 1995b. Kommunikative Stilistik einer sozialen Welt "kleiner Leute" in der Mann heimer Innenstadt. Mit zwei Beiträgen von Werner Kallmeyer. Kommunikation in der Stadt. (Schriften des Instituts für deutsche Sprache, Bd. 4.3). Berlin - New York.

Labov, William. 1972. Sociolinguistic Patterns. Pennsylvania. 
Levinson, Stephen. 1988. "Conceptual Problems in the Study of Regional and Cultural Style." In: Norbert Ditumar \& Peter Schlobinski (eds.). The Sociolinguistics of Urban Vernaculars. Case Studies and their Evaluation. Berlin, 161-190.

McDermott, R. P. \& K. Gospodinoff. 1979. "Social Contexts for Ethnic Borders and School Failure." In: A. Wolfgang (ed.), Nonverbal Behavior. New York, 175-195.

Mannheim, Karl. 1952. "On the Interpretation of "Weltanschauung"." In: Karl Mannheim. Essays in the Sociology of Knowledge. Ed. by Paul Kecskemeti. London, 33-83.

Moerman, Michael. 1988. Talking Culture. Ethnography and Conversation Analysis. Philadelphia.

Sacks, Harvey. 1972. "On the Analyzability of Stories by Children." In: John Gumperz \& Dell Hymes (eds.), Directions in Sociolinguistics. New York, 325-345.

Sacks, Harvey. 1979. "Hotrodder: A Revolutionary Category." In: George Psathas (ed.), Everyday Language. Studies in Ethnomethodology. New York, 7-21.

Sandig. Barbara. 1986. Stilistik der deutschen Sprache. Berlin.

Schütz, Alfred. 1962-1966. Collected Papers. Vol.I-III. Den Haag.

Schwitalla, Johannes. 1995. Kommunikative Stilistik zweier sozialer Welten in MannheimVogelstang. Kommunikation in der Stadt. (Schriften des Instituts für deutsche Sprache, Bd. 4.4). Berlin - New York.

Streeck, Jürgen. 1985. "Kulturelle Kodes und ethnische Grenzen. Drei Theorien über Fehlschläge in der interethnischen Kommuniaktion." In: Jochen Rehbein $(\mathrm{Hg}$.), Interkulturelle Kommunikation. Tübingen, 103-121.

Tannen, Deborah. 1984. Conversational Style. Analyzing Talk among Friends. Norwood, N. J.

Turner, Victor 1975. Dramas, Fields, and Metaphors. Symbolic Action in Human Society. Ithaca London.

Willis, Paul. 1981. 'Profane Culture'. Rocker, Hippies: Subversive Stile der Jugendkultur. Frankfurt/M.

\section{Appendix: Transcription}

Our transcription uses the signs of the German alphabet in analogy to the rules of pronunciation in German for the representation of the phonological and phonetic features of the spoken dialectal language. In addition, we use the following notation for prosodic features:

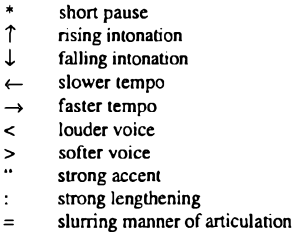

